\title{
Influence of Cinepazide Maleate on Vascular Endothelial Function of Patients with Acute Myocardial Infarction
}

\author{
Jiaming Niu* and Zhaoling Ma \\ Laiwu City People's Hospital of Shandong Province, Laiwu, Shandong 271100, China
}

\begin{abstract}
Objective: To study influence of cinepazide maleate on vascular endothelial function of patients with acute myocardial infarction. Methods: 150 cases of patients with acute myocardial infarction were divided into the observation group and the control group, two groups were treated by conventional therapy about acute myocardial infarction, the observation group added 5\%GS250 mL + cinepazide maleate $160 \mathrm{mg}$ IV drip q.d, the control group added 5\%GS250 mL IV drip q.d, the treatment course were 3 weeks, changes of vascular endothelial function and the blood serum no level before and after treatment were detected. Result: vascular endothelial function after treatment in observation group were obviously improved than that before treatment $(\rho=0.03)$ , blood serum no level was obviously increased $(\rho<0.05)$; about 3 weeks after treatment, vascular endothelial function in the observation group was obviously better than that of the control group $(\rho=0.04)$, the blood serum no level of the observation group was obviously higher than that of the control group $(\rho<0.05)$. Conclusion: Cinepazide maleate remarkably improves vascular endothelial function of patients with acute myocardial infarction.
\end{abstract}

\author{
KEYWORDS \\ Acute myocardial infarction \\ Vascular endothelial function \\ Cinepazide maleate
}

\section{Introduction}

Cinepazide maleate is a novel substituted piperazines, has a variety of pharmacological effects such as endogenous adenosine to improve efficiency, calcium channel blockers, phosphodiesterase inhibition, etc. There are more clinical study on vasorelaxation action while less reports on effect of vascular endothelial function. In this paper, intravenous infusion of cinepazide maleate was administrated to patients

Copyright $\odot 2015$ Jiaming Niu et al.

doi: $10.18686 /$ aem.v4i3.1

Received: August 3, 2015; Accepted: September 4, 2015; Published online: September 13, 2015

This is an open-access article distributed under the terms of the Creative Commons Attribution Unported License (http://creativecommons.org/ licenses/by-nc/4.0/), which permits unrestricted use, distribution, and reproduction in any medium, provided the original work is properly cited.

${ }^{\star}$ Corresponding author: Laiwu City People's Hospital of Shandong Province, Laiwa, Shandong 271100, China. E-mail: zll010@sina.com with acute myocardial infarction by the randomized, control design method, to observe the changes of endothelial function.

\section{Materials and methods \\ 2.1. Study subjects}

150 patients with acute myocardial infarction treated in our hospital from March 2010 to December 2011 were selected as the study subjects. Inclusion criteria: (1) meet the diagnostic criteria of acute myocardial infarction [1-2]; (2) any vascular disease has not occurred; (3) excluding liver, gallbladder, pancreas, thyroid and kidney disorders; (4) have regular eating habits and a certain amount of activity; (5) non-diabetic patients; (6) hypertension. 150 patients were randomly divided into two groups, the observation group was 78 cases and the control group was 72 cases. The control group and observation group were roughly 
matched in age, gender, smoking, taking drugs, alcohol consumption, and body mass index, etc.

General information of the subjects (Table 1) displays there was no significant difference in gender, age, smoking, taking drugs, alcohol consumption, and body mass index and so on.

Table 1. General information.

\begin{tabular}{ccc}
\hline & The observation group & The control group \\
\hline $\begin{array}{c}\text { Case(male/female) } \\
\text { Age(years) }\end{array}$ & $78(40 / 38)$ & $72(37 / 35)$ \\
$\begin{array}{c}\text { Smoking(number) } \\
\text { Alcohol }\end{array}$ & $10.4 \pm 10.8$ & $54.8 \pm 9.5$ \\
$\begin{array}{c}\text { consumption(number) } \\
\text { Body mass index(kg/ } \\
\text { m2) }\end{array}$ & 15 & 8 \\
ACEI/ARB & $25.1 \pm 0.7$ & 12 \\
$\begin{array}{c}\text { Ca channel } \\
\text { antagonists }\end{array}$ & 45 & $24.9 \pm 0.6$ \\
B receptor blocker & 29 & 41 \\
\hline
\end{tabular}

\subsection{Methods}

On the basis of routine treatment of myocardial infarction, the observation group added 5\%GS250 mL + Cinepazide maleate $160 \mathrm{mg}$ IV drip q.d, the control group added 5\%GS250 mL iv drip q.d, the treatment course were 3 weeks.

\subsection{Specimen collection and testing}

Three $\mathrm{mL}$ elbow venous blood was taken from all the subjects after fasting for 12 hours in the morning of selection and 3 weeks after treatment. Immediately centrifuge for 25 minutes with high speed at room temperature (3000 $\mathrm{rpm} / \mathrm{min})$, separated serum was stored in the refrigerator under $-70{ }^{\circ} \mathrm{C}$ to be measured, uniform determination of $\mathrm{NO}$ in serum was made.

\subsection{Determination of vascular endothelial function}

Non-invasive detection of vascular endothelial function is made before and 3 weeks after treatment respectively. Determination of vascular endothelial function: use the hpsonos 5500 color doppler ultrasound system (HewlettPackard Development Company), transducer frequency is $10 \mathrm{mhz}$, synchronously record the ECG. The subjects take a break for $10 \mathrm{~min}$ before testing, stay in supine position, right upper arm outreach for 15 degrees. Selected 2 15 $\mathrm{cm}$ range of brachial artery in the cubital fossa as the target artery, $4 \mathrm{~cm}$ depth, freeze after getting satisfactory long axis image of the brachial artery. At the top of the $\mathrm{R}$ wave in ECG, measure ventricular end-diastolic diameter of brachial artery, take the average of 3 cycles as a basis inner diameter of brachial artery (D0), mark on the skin of the test location for repeated operations. Bind cuff blood pressure monitor to the right forearm and inflate until blood pressure monitor readings reach to $300 \mathrm{mmHg}$, maintain for $5 \mathrm{~min}$, quickly deflate, measure ventricular end-diastolic diameter of brachial artery (D1) of original marked position again within $90 \mathrm{~s}$. The patient rest for more than $10 \mathrm{~min}$, give sublingual nitroglycerin $0.5 \mathrm{mg}, 5 \mathrm{~min}$ later the brachial artery diameter (D2) is measured. Consider the brachial artery diameter change percentages before and after reactive hyperemia and taking nitroglycerin as endothelium-dependent vasodilation (Flow-mediated dilation, FMD) and non-endothelial dependent relaxation (endothelium-independent dilatation, EID). Calculated as: $\mathrm{FMD}=(\mathrm{D} 1-\mathrm{D} 0) / \mathrm{D} 0$ $\times 100 \%$; EID $=(\mathrm{D} 2-\mathrm{D} 0) / \mathrm{D} 0 \times 100 \%$.

\subsection{Statistics analysis}

Using the SPSS 11.0 statistical software for statistical analysis: measurement data is represented as $(\bar{x} \pm s)$; comparison between groups and within group is made by $t$ test and analysis of variance, respectively; $p<0.05$ is considered to be statistically significant difference.

\section{Results \\ 3.1. the FMD, EID changes of brachial artery in each group before and after 3 weeks ( see table 2 ).}

Table 2. The FMD, EID changes of brachial artery in each group before and after 3 weeks.

\begin{tabular}{ccccc}
\hline & \multicolumn{2}{c}{ The control group } & \multicolumn{2}{c}{ the observation group } \\
\cline { 2 - 5 } & 3 weeks ago & after 3 weeks & 3 weeks ago & after 3 weeks \\
\hline FMD (\%) & $8.9 \pm 0.4$ & $9.9 \pm 1.4$ & $9.0 \pm 0.4$ & $14.1 \pm 1.2$ * \\
EID (\%) & $14.6 \pm 4.5$ & $18.5 \pm 5.9$ & $17.7 \pm 4.2$ & $18.5 \pm 4.0$ \\
\hline
\end{tabular}

FMD: flow- mediated vasodilation, EID: nitroglycerin- mediated vasodilation

*: comparison of before and after 3 weeks, the observation group FMD improved significantly ( $p=0.03) ; 3$ weeks after treatment, the FMD of observation group improved more significantly than the control group $(p=0.04)$;

\subsection{Serum NO changes of each group before and after 3 weeks}

Serum NO changes: serum NO level in observation group and control group has no significant difference 3 weeks ago; after 3 weeks, the serum NO level of observation group increases significantly $(p<0.05)$ while the control group has no significant difference, the serum NO level of observation group is significantly higher than the control group $(p<0.05)$ (Table 3$)$.

Table 3. Serum NO changes of each group before and after 3 weeks.

\begin{tabular}{lcccc}
\hline & \multicolumn{2}{c}{ The control group } & The observation group \\
\hline NO & 3 weeks ago & After 3 weeks & 3 weeks ago After 3 weeks \\
$(\mu$ mol/l) & $41.0 \pm 5.1$ & $42.3 \pm 4.3$ & $39.2 \pm 3.8$ & $61.0 \pm 7.5^{*}$ \\
\hline NO: nitric oxide \\
*means the significant change in serum NO of observe group 3 weeks \\
later compared with 3 weeks ago $(p<0.05)$; means serum NO level in
\end{tabular}


observation group is significantly higher than the control group after 3 weeks $(p<0.05)$;

\section{Discussion}

Cinepazide maleate is a novel substituted piperazines, has a variety of pharmacological effects such as endogenous adenosine to improve efficiency, calcium channel blockers, phosphodiesterase inhibition, etc. [3]. Cinepazide maleate has weak inhibitory effect of calcium ion, it also has good spasmolysis and expansion on coronary artery, cerebral arteries and peripheral vessels [4]. Cinepazide has a unique synergy of adenosine. It blocks adenosine inactivation process by blocking the reabsorption of adenosine and inhibition of adenosine deaminase activity, delay the metabolism of adenosine, thereby increasing the lesion local concentration of endogenous adenosine, regulating peripheral artery and coronary artery diastolic function [5]. Through using cinepazide maleate for 3 weeks on the basis of conventional therapy in patients with acute myocardial infarction, the study shows that cinepazide maleate has effect on improving vascular endothelial function, vascular active substance NO which associated with the vascular endothelial dilatation function is significantly increased.

Xiaoqiu zhou [6], Lijing zhao [6] and others have made a study on unstable angina application patients who using cinepazide maleate. The results shows application of cinepazide maleate injection on the conventional treatment in UAP treatment can obviously improve the clinical curative effect, clinical symptoms and exercise tolerance, reduce whole blood low shear viscosity, whole blood high shear viscosity, plasma viscosity, platelet aggregation, platelet adhesion rate, improve ECG manifestations, reduce acute myocardial infarction, arrhythmia and other severe cardiovascular complications. The study by Huapin wang, et al [8] found that use of cinepazide maleate combined with xuesaitong in the treatment of UAP has synergy in improving the hemorheology and atherosclerosis inflammatory reaction. Xiaohua Luo, et al [9] found that cinepazide maleate combined with irbesartan can effectively control blood pressure, obviously improve clinical symptoms and ECG curative effect of angina pectoris patients, reduce the frequency of angina attacks, improve myocardial ischemia and enhance heart function. Chengjun shi, et al [10] found combination of sodium tanshinone IIA sulfonate and cinepazide maleate in the treatment of angina pectoris of coronary heart disease can improve clinical syndrome and the electrocardiogram in patients with coronary heart disease. Musheng Yu, et al [11] shows that after intravenous infusion of cinepazide maleate, diabetic patients artery FMD improves significantly, indicating improving vascular endothelial function. The above study shows cinepazide maleate can significantly improves vasodilation function and adenosine synergies, expand blood vessels, has good spasmolysis and expansion on coronary artery, cerebral arteries and peripheral vessels, also can inhibit platelet aggregation, reduce the production of oxygen free radicals, reduce neutrophil chemotactic effects on vascular endothelial cells, increase the toughness and deformation capacity of cells and decrease blood viscosity, thereby improving the microcirculation perfusion. This study suggests that cinepazide maleate can significantly improve vascular endothelial function, increased endothelial-derived relaxing factor NO, it's mechanism need further research.

\section{Conflicts of interest}

These authors have no conflicts of interest to declare.

\section{Authors' contributions}

These authors contributed equally to this work.

\section{Reference}

1. Ke YN, Chen JL. Unstable angina and non ST segment elevation myocardial infarction diagnosis and treatment guidelines. Chinese journal of cardiology. 2007;35(4):295340.

2. Sun JA, Fu XH. Diagnosis and treatment of ST-segment elevation acute myocardial infarction. Clinical focus. 2004;19(3):131-134.

3. Zhang XX, Han PH. Pharmacological action and clinical application of cinepazide maleate. China pharmacy. 2007;18(26):2060-2062.

4. Geng HY, Wang SH. Practical therapeutics. Beijing : people's medical publishing house. 2006:1060-1061.

5. Yang L, Xia Y, Li XJ, et al. Evaluation of Doppler guide wire on adenosine preconditioning protection of coronary microcirculation function. Journal of clinical cardiology. 2004;20(6):357-359.

6, Zhou XQ, Chen S. Cinepazide maleate in treatment of unstable angina pectoris. The journal of practical medicine. 2009;25(2):272-273.

7. Zhao LJ. Cinepazide maleate injection on unstable angina pectoris analysis. Journal of jilin college of pharmacy. 2010;31(4):198-192.

8. Wang HP, Lu ZG. Effect observation of cinepazide maleate combined with xuesaitong injection on unstable angina pectoris. Guangdong medical journal. 2009;30(11):17351736.

9. Luo XH, Hu HH, Ma Y. Cinepazide maleate combined with irbesartan in treatment of 25 cases of senile hypertension complicated with coronary heart disease angina pectoris. Shaanxi Medical Journal. 2009;39(8):1045-1046.

10. Cheng J, Wang ZL, Zhao HC. Combination of sodium tanshinone IIA sulfonate and cinepazide maleate in treatment of angina pectoris. Shandong medical journal. 2011;51(17):71-72.

11. YU MS, Liang TS, et al. Clinical research of improvement of cinepazide maleate on vascular endothelial function in type 2 diabetic patients. Shandong pharmaceutical. 2009;49(24):79-80. 